\title{
Labor Education in Primary and Secondary Schools in the New Era Based on Modern Information Technology
}

\author{
Liansen Wen* \\ Chongqing Qijiang Information Technology and Equipment Center, China \\ *Corresponding author: Liansen Wen, Wls910218@163.com
}

\begin{abstract}
With the rapid development of information technology represented by artificial intelligence (AI), there has been a great impact on educational methods, educational behaviors, and educational models. It can even be said that there is a fundamental change. Especially under the influence of the pandemic, educational behaviors have undergone radical changes. The education management information system in primary and secondary schools strengthens the service of labor education for primary and secondary school students, with a data analysis system for labor education. A survey on labor education in 103 primary and secondary schools in the region has been carried out. Information technology can well improve the form of labor education in primary and secondary schools and promote the development of labor education. Big data can be used to objectively analyze the problems of labor education in primary and secondary schools, thus proposing a new era of labor education data analysis system and management for primary and secondary schools.
\end{abstract}

Keywords: New era; Primary and secondary schools; Labor education; Problems; Countermeasures

Publication date: November 2021; Online publication: November 30, 2021

\section{Introduction}

Labor education is an important component in the socialist education system with Chinese characteristics, which directly determines the labor spirit, labor value orientation, and labor skill level of socialist builders and successors ${ }^{[1]}$. Only by understanding the status quo, analyzing the problems, and researching on countermeasures, then labor education in primary and secondary schools can be better promoted in the new era.

\section{Ease of use}

\subsection{Status quo and problems of labor education in primary and secondary schools}

The problems of labor education in primary and secondary schools have been discussed in the academic circle. The results from these discussions are mostly based on academic theoretical discussions; it is rare to come across those in the form of surveys. Taking Qijiang District as an example, a survey was carried out on 103 primary and secondary schools. From the survey, four major conditions and seven major problems have been raised (Table 1). 
Table 1. Statistics from the survey of 103 primary and secondary schools

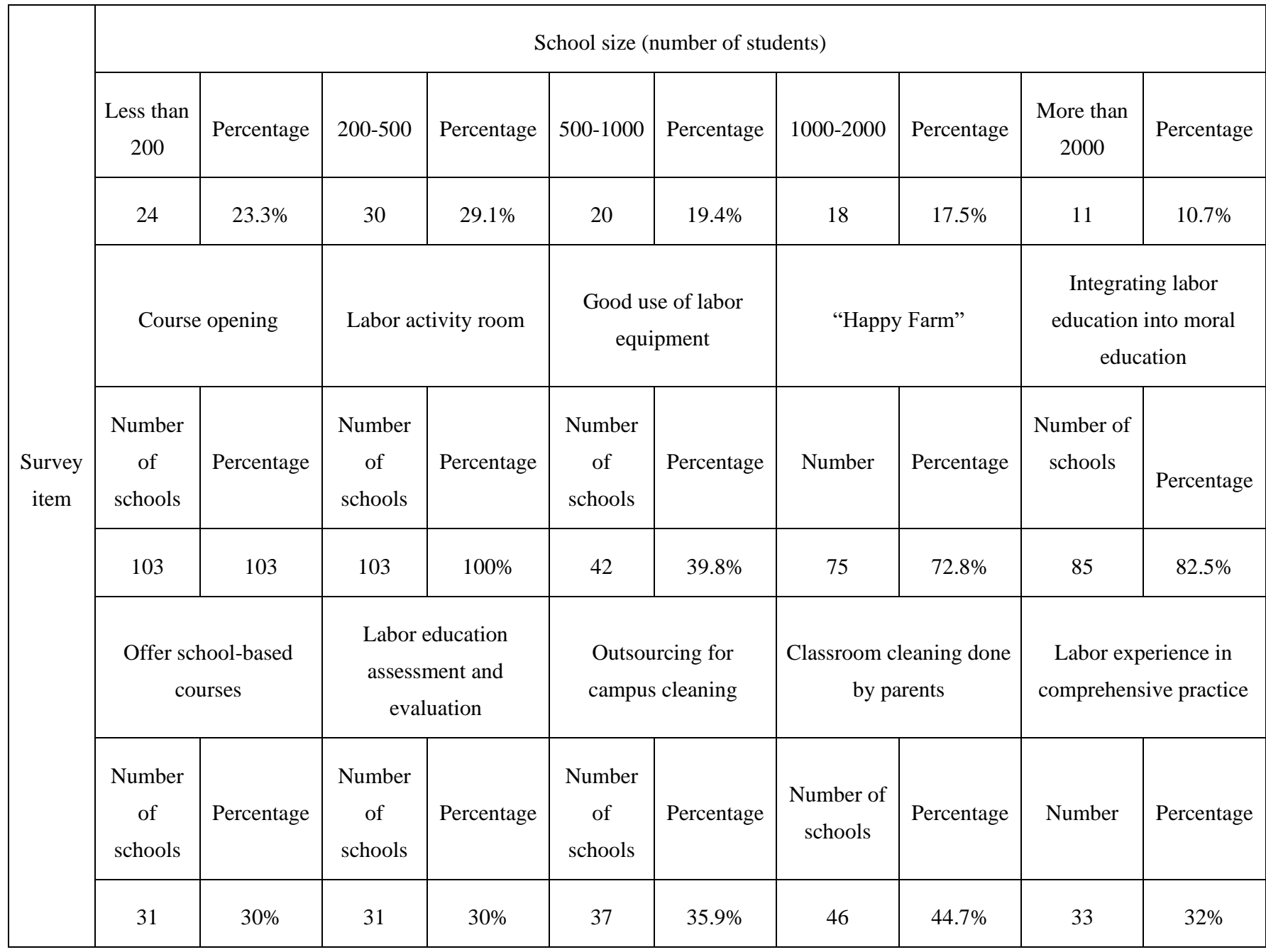

Note: There are 11 schools with more than 2,000 students, and each school has only one labor technology activity room, which obviously does not meet the needs of labor technology courses.

\subsubsection{Feedback on the reality of labor problems in primary and secondary schools}

(1) Every school has set up labor courses and has integrated them into the general class schedule and class schedule. Each class has one session per week, beginning from the third grade of elementary school. Whether the courses are able to keep up with the national pattern remain undetermined. It is necessary to based back on the actual situation of schools in various places as well as adapt to the local conditions and school conditions ${ }^{[2]}$.

(2) The construction of labor activity rooms is in accordance with the requirements of higher-level departments; in addition, the balanced and standardized construction of compulsory education in schools are basically up to the standard, equipped with labor activity rooms and related equipment. This is the current distribution of quantitative standards.

(3) Comprehensive practice activities are means of promoting the development of labor education. Among them, 75 schools have built labor practice bases, such as "Happy Farm," in or near schools; in the whole district, there are 3 agricultural practice bases with 55 schools that are assigning students to these agricultural practice bases for planting and picking activities (Table 2). 
Table 2. Teachers' understanding of labor education (200 questionnaires and interviews)

\begin{tabular}{|c|c|c|c|c|c|c|c|}
\hline \multicolumn{2}{|c|}{$\begin{array}{c}\text { Value recognition of labor } \\
\text { education }\end{array}$} & \multicolumn{6}{|c|}{ The degree to which schools attach importance to labor education } \\
\hline & Percentage & Important & Percentage & Moderate & Percentage & Irrelevant & Percentage \\
\hline 200 & $100 \%$ & 102 & $51 \%$ & 97 & $43.5 \%$ & 11 & $5.5 \%$ \\
\hline \multicolumn{4}{|c|}{ Participation in teaching and research related to labor education } & \multirow{2}{*}{\multicolumn{2}{|c|}{ Organized social practice }} & \multirow{2}{*}{\multicolumn{2}{|c|}{$\begin{array}{c}\text { Labor education in moral } \\
\text { education }\end{array}$}} \\
\hline \multicolumn{2}{|c|}{ School level } & \multicolumn{2}{|c|}{ District (county) level and above } & & & & \\
\hline $\begin{array}{c}\text { Number of } \\
\text { people }\end{array}$ & Percentage & $\begin{array}{l}\text { Number of } \\
\text { people }\end{array}$ & Percentage & $\begin{array}{l}\text { Number of } \\
\text { people }\end{array}$ & Percentage & $\begin{array}{c}\text { Number of } \\
\text { people }\end{array}$ & Percentage \\
\hline 36 & $18 \%$ & 11 & $10 . \%$ & 103 & $51.5 \%$ & 168 & $84 \%$ \\
\hline
\end{tabular}

(4) Moral education activities are permeated through labor activities. In fact, it is the integration of labor education with moral education. Alike like the nodes of "Learn from Lei Feng Day," Labor Day on May 1, and Chongyang Festival on September 9, implemented yearly by 85 schools, where students go to the streets and communities, visit nursing homes, and other off-campus destinations to carry out activities, such as cleaning, sanitation, picking up rubbish, and other housework activities, primary and middle school students actively take part in housework, take the initiative to clean the campus, participate in social practice, as well as enthusiastically volunteer their service in experiencing labor creation ${ }^{[3]}$. This natural integration of labor education with moral education is a supreme realm for human education (Table 3).

Table 3. Students' understanding of labor education (1,000 questionnaires and interviews)

\begin{tabular}{|c|c|c|c|c|c|c|c|}
\hline \multicolumn{2}{|c|}{$\begin{array}{l}\text { Value recognition of labor } \\
\text { education }\end{array}$} & \multicolumn{2}{|c|}{$\begin{array}{c}\text { Participation in classroom } \\
\text { cleaning }\end{array}$} & \multicolumn{2}{|c|}{$\begin{array}{l}\text { Participation in campus } \\
\text { cleaning }\end{array}$} & \multicolumn{2}{|c|}{$\begin{array}{c}\text { Participation in } \\
\text { comprehensive practice }\end{array}$} \\
\hline $\begin{array}{l}\text { Number of } \\
\text { people }\end{array}$ & Percentage & $\begin{array}{c}\text { Number of } \\
\text { people }\end{array}$ & Percentage & $\begin{array}{l}\text { Number of } \\
\text { people }\end{array}$ & Percentage & $\begin{array}{l}\text { Number of } \\
\text { people }\end{array}$ & Percentage \\
\hline 748 & $74.8 \%$ & 568 & $56.8 \%$ & 496 & $49.6 \%$ & 513 & $513 \%$ \\
\hline \multicolumn{2}{|c|}{$\begin{array}{l}\text { Participation in moral } \\
\text { education }\end{array}$} & \multicolumn{2}{|c|}{$\begin{array}{l}\text { Participation directly in } \\
\text { agricultural labor }\end{array}$} & \multicolumn{2}{|c|}{ Able to wash and cook } & \multicolumn{2}{|c|}{ Doing housework } \\
\hline $\begin{array}{l}\text { Number of } \\
\text { people }\end{array}$ & Percentage & $\begin{array}{l}\text { District and } \\
\text { county level }\end{array}$ & Percentage & $\begin{array}{c}\text { Number of } \\
\text { people }\end{array}$ & Percentage & $\begin{array}{l}\text { Number of } \\
\text { people }\end{array}$ & Percentage \\
\hline 567 & $56.7 \%$ & 27 & $0.27 . \%$ & 303 & $30.3 \%$ & 468 & $46.8 \%$ \\
\hline
\end{tabular}




\subsubsection{Current problems of labor education in primary and secondary schools}

(1) Labor courses are arranged for Chinese, mathematics, and other subject teachers in the form of "arranging lessons." Schools lack planning and assessments for labor education; their entire focus is on examination subjects, such as mathematics and languages. Labor classes that are arranged in class schedules exist in name only.

(2) Labor activity rooms are seldom used, and some exist as decorations. Usually, students are not charged for any loss of equipment from these rooms, and there are no special funds to maintain these rooms.

(3) Some schools contract "Happy Farm" to chefs or family members of teachers to handle inspections and assessments; other schools contract school cleaning and sanitation to social cleaning companies, thus discarding existing labor and education resources.

(4) Public welfare activities only allow certain students to join, particularly class cadres. These activities do not provide opportunities for all members to participate. Even public welfare activities are only formalities, where they lack the refinement of educational value.

(5) In some schools, parents are allowed to clean the classroom for their children. In other schools, teachers punish students who are late or violate school rules by cleaning and working on other labor contents, thus labelling "labor" as "bad."

(6) The vast majority of parents regard knowledge learning as their only goal. They do not allow their children to help around with housework at all; instead, they send their children to multiple tuition classes. These classes take up a lot of time.

(7) The evaluation of labor education is lacking. Schools and education departments only give a certain weight symbolically to the evaluation of labor education, which lacks clear guidance and metrics.

The reasons for these problems can be summarized as follows: first, there are safety risks in labor activities, and no one wants to cross the red line; second, labor education is not an examination subject; therefore, it has minimal impact on the performance of schools and teachers; third, it is the permeation and temptation of the idea of "profit without work" on the internet that makes primary and middle school students contempt and avoid labor; fourth, parents do not pay adequate attention to labor education, and some parents even mislead their children in their perspective toward labor education; thus, labor education appears to be isolated, and there are hardly any achievements in the education; fifth, labor education includes thinking class, labor technique class, labor class, comprehensive practice class, and moral education activities ${ }^{[4]}$, but each educational stage lacks clear definitions and requirements in the labor concept, labor attitude, labor value, labor knowledge, labor skills, etc.; sixth, the labor evaluation system is lacking, in which it is difficult to accurately quantify the labor process, results, and the evaluation operation.

\subsection{Countermeasures to strengthen labor education in primary and secondary schools in the new era}

This is the advent of the new era. Today's primary and secondary school students are the builders and successors of China's socialist power as well as the bearers of a world community with a shared future. The Central Committee of the Chinese Communist Party and the State Council attach great importance to labor education. It is the common responsibility of the whole society to improve the labor literacy among primary and middle school students in terms of labor concepts, attitude, knowledge, skills, and creation. To this end, several suggestions have been made. 
(1) Raise awareness and change concepts

Guided by "Xi Jinping's Thought on Socialism with Chinese Characteristics for a New Era," it is necessary to conscientiously implement the Opinions on Comprehensively Strengthening Labor Education in Universities and Primary Schools in the New Era by the Central Committee of the Communist Party of China and the State Council as well as the Guiding Guidelines for Labor Education in Universities and Primary Schools (for Trial Implementation) by the Ministry of Education. Political departments, education departments, and schools should raise awareness, change their concepts, perform their duties, make effort to strengthen labor education, and establish the new concept of "labor glory" in the whole society.

(2) Strengthen network governance and purify the network environment

It is important to strengthen network governance, purify the network environment, and eliminate negative information on the network, such as despising labor and making purposeless effort. Give full play to the advantages of wide network coverage and fast dissemination to promote labor value, knowledge, and skills as well as encourage labor creation among young people.

(3) Call for legislation on education safety risks

Although the Ministry of Education has issued and implemented the Measures for Handling Student Injury Accidents in Decree No. 12, this measure is only an administrative regulation and has not been upgraded as a law. Only by perfecting the law, using legal means to protect educational and teaching activities, as well as clarifying the responsibilities of all parties in the education process, then schools can freely take up the responsibility to carry out educational practices including labor education.

(4) Formulate labor curriculum standard and training objectives

The state should formulate labor curriculum standards and labor skills training objectives for each educational stage and introduce guiding principles for evaluation. Local education departments should strengthen the security and the construction of labor education. Schools should ensure that the national labor education curriculum is appropriate and implemented. They should also develop school-based courses, implement education simultaneously, and include the results of labor education in students' progress files.

(5) Strengthen the training of teachers' labor literacy

It may be beneficial to include labor education in the full training and special training of teachers, change the mindset of teachers, infiltrate labor education in daily subject teaching, and improve students' labor skills in curriculum teaching. Students' labor literacy should be cultivated in the whole process of teaching.

(6) Strengthen labor education and scientific research

The research on "labor plus internet" should be strengthened. Modern information technology, big data, artificial intelligence, and other technical means should be used to record and scientifically evaluate the labor process and labor skills of primary and secondary school students.

(7) Consider the local reality and carry out innovative labor education

While carrying out traditional labor education, schools should take into consideration of the local reality and keep up with the development of science and technology as well as the industrial changes, accurately grasp the new changes in labor tools, labor technology, and labor forms in the new era, innovate the content, methods, and models of labor education, as well as enhance the timeliness of labor education ${ }^{[5]}$. 
(8) Scientifically carry out supervision and evaluation of labor education

Competent education departments should formulate implementation rules and evaluation system for labor education in primary and secondary schools as well as incorporate labor education into schools' performance supervision and assessment.

\section{Conclusion}

In short, the joint efforts of the party and government, social governance, legislative guarantee, school promotion, family cooperation, as well as supervision and evaluation can effectively promote labor education in primary and secondary schools in the new era.

\section{Disclosure statement}

The author declares that there is no conflict of interest.

\section{References}

[1] 2020, Opinions on Comprehensively Strengthening Labor Education in Universities, Middle Schools and Primary Schools in the New Era by the Central Committee of the Communist Party of China and the State Council (updated March, 2020).

[2] 2020, The Ministry of Education Labor Education Guidelines for Universities, Middle Schools and Primary Schools (Trial) Textbook [2020] No. 4.

[3] Xie X, Li X, 2014, Difficulties and Solutions of School Labor education. Frontier Economy and Culture (11): 2.

[4] Liu Y, 2019, Construction of Labor Education Model under the Framework of Comprehensive Practical Activity Curriculum. New Curriculum Research, 1(4): 2.

[5] He Y, Zong A, 2019, Study on the Status Quo, Problems and Countermeasures of Labor Education in Primary and Secondary Schools. Youth Journal, (1): 6. 